\title{
The dilemma of scope and scale for construction professional service firms
}

Carol Jewella ${ }^{\mathrm{a}}$ Roger Flanagan ${ }^{\mathrm{a}}$ and Weisheng $\mathrm{Lu}^{\mathrm{b}}$

a School of Construction Management and Engineering, University of Reading, Reading, UK

b Department of Real Estate and Construction, University of Hong Kong, RM 515, 5/F, Knowles Building, The University of Hong Kong, Pok Fu Lam, Hong Kong

\begin{abstract}
Construction professional service (CPS) firms sell expertise founded on knowledge, experience, technical competence, and provide innovative solutions. Large CPS firms, during their internationalisation process, face a dilemma of scope and scale. Increasing both the scale/scope of services of a firm may lead to economies of scale/scope, but growth can also lead to diseconomies, when the added cost of extra production and the increased complexity of diversification no longer create benefits. The aim of this paper is twofold: (a) to investigate the dilemma of scope and scale for CPS firms; and (b) to investigate the factors influencing the decisions in dealing with the dilemma. Qualitative data from the interviews was underpinned by secondary data from CPS firms' annual reports and analysts' findings. The findings showed eight key influences on the scope and scale of a CPS firm: growth strategy, profitability, competitiveness, reputation, serving the client's needs, internationalisation, localisation, and ownership constraints. The research provides valuable insights into the sophisticated operations of international CPS, will support business executives' strategic decisions in gleaning economies of scope and scale, and avoiding their diseconomies.
\end{abstract}

Keywords: Economies of scope; economies of scale; construction; professional services; growth.

\section{Introduction}

Globalisation has changed the nature of competition (Hatzichronoglou, 1996, p. 837), prompting increasing numbers of CPS firms to internationalise and export their services. The transformation is based on the need for the firms to: 1) sustain growth and profitability; 2) minimise the risk of an over-reliance on working in a single domestic market with a cyclical and fluctuating demand; 3) expand overseas having outgrown their domestic market; and 4) to follow clients seeking to work in new geographic areas (Jewell, 2011). Statistics published by the Engineering News-Record (ENR), for example, show that the ENR's top 200 international design firms (TID 200) generated \$57.66 billion in CPS revenue in 2010 from projects outside their respective home countries (Reina and Tulacz, 2011). Advanced technology, fast transportation, convenient communications, effective knowledge transfer, integrated markets, and trade liberalization have all helped transcend traditional country 
boundaries and take CPS business into the international arena (Lu et al., 2013).

Many CPS firms have grown in scope and scale, as they have internationalised. CPS firms are client-led; they have increased the scope of their competencies to meet clients' changing needs. They have diversified themselves into a wide range of specialisation including architecture, engineering, landscaping, and so on. On the other hand, large international CPS firms have endeavoured to increase their scale. It is believed that: 1) the higher the annual revenue of the firm (or the larger the number of employees), the greater the ability to offer clients more services, and the greater the opportunity to grow, and; 2) growth can help to rationalise operating costs, thus becoming more competitive, and so winning more projects, and increasing annual revenue and profits. However, growth and diversification can also lead to possible diseconomies of scale/scope, when the added cost of extra production and the increased complexity of diversification no longer create benefits. This echoes Nayyar (1993), who points out that, for service firms, achieving economies of scope can entail high transaction costs due to the degree of co-ordination needed between business units for sharing say, management skills and technology.

Existing theories of firms' growth in scope and scale mostly focus on the manufacturing sector, without considering the characteristics of service firms. For example, economies of scale can more easily be achieved by manufacturing firms who have the ability to produce more goods at a lower unit cost by improving their production processes/facilities or relocating to low-wage economies. For CPS and other service firms, economies of scale are restricted to headquarter and 'back office' functions (Segal-Horn, 2003) such as IT systems, marketing, human resource management, and other management systems. Work is site-specific and therefore little opportunity to locate production in, say, a low wage economy. New theories and a greater understanding are needed when CPS firms face a dilemma in growing/diversifying to maximise revenue and employee output, while simultaneously being locally responsive to clients.

The aim of this research is to investigate the dilemma of scope and scale for CPS firms. There are two specific research objectives: (a) To understand the underlying theoretical concepts of economies of scope and scale and their influence on CPS firms; (b) To identify what influences the scope and scale of CPS firms' operations. The next section is a literature review, introducing the definitions of CPS and their characteristics by comparing them with manufacturing or services in general. The two important constructs, economics of scope and scale, are scrutinised by contextualising them in construction-related professional services in their internationalization process. Section 3 presents the methodology; a triangulation of the data from interviews, company annual reports, and published analyst/financial reports is 
conducted, with the facilitation of a "growth timeline" particularly invented for this study. Section 4 elaborates the analyses, discussions, and findings. Conclusions are drawn in Section 5.

\section{Literature review}

\section{What is a CPS firm?}

For this research, CPS firms are those as defined under Section $M$ of the UK Standard Industry Classification (SIC) 2007 (ONS, 2007, Jewell et al., 2010) i.e. 71 (Architectural and engineering activities; technical testing and analysis), and 74 (Other professional, scientific and technical activities). This classification covers architects, design engineers, cost consultants and other construction-related professional services. CPS can be considered as including a wide range of knowledge-intensive realms such as architecture, engineering, environmental, geotechnical engineering, landscape architecture, urban planning, surveying, and their combinations, as well as construction-related accountancy, legal, and information and communication technology services.

A CPS fits the general definition of a service (an activity, deed or process and iteration). Services differ from manufactured goods in that the demand for them is extrinsic; they are bespoke and dependent on each client's requirements. Unlike manufactured goods, they cannot be stored, marketed and sold 'off-the-shelf'. Løwendahl (2007) thus points out that previous theories on organizations and competitive strategy were developed for use in manufacturing and so are not necessarily applicable to professional services, which have unique characteristics.

But a CPS is also distinguished from general services by its customisation and customer interaction. Construction projects are characterised by their uniqueness (Dubois and Gadde, 2002). Buildings and infrastructure are fixed commodities and projects are designed and built for local environments, they are not transportable (Gann, 1996). Every construction project is site-specific and purpose-built and so customer interaction is very important and localisation is high on the agenda of CPS firms in the global market (Malcic, 2011; McCann, 1996). The characteristics of CPS firms have been summarized by Jewell et al. (2010) as: Location specific; often client led; highly customized bespoke output; extrinsic demand; project based; heterogeneous, and; knowledge intensive. With these characteristics, CPS firms' growth through expanding scope and scale, particularly in an internationalisation context, should present different patterns.

\section{Economics of scope and scale}

Coined by Panzar and Willig (1977; 1981), economics of scope and scale probably could be 
ranked as the most popular and powerful concepts in explaining modern corporate behaviours such as growth, merger and acquisitions (M\&A), and diversification. "Economies of scope exist when it is cheaper to produce two products together (joint production) than to produce them separately" (OECD, 2011). "Economies of scope exist if the firm achieves savings as it increases the variety of goods and services it produces" (Besanko et al., 2009). "Economies of scope arise from the sharing or joint utilization of inputs" (Bailey and Friedlaender, 1982, p. 1026). "Economies of scale refers to the phenomenon where the average costs per unit of output decrease with the increase in the scale or magnitude of the output being produced by a firm” (OECD, 2011). "Economies of scale exist if the firm achieves unit-cost savings as it increases the production of a given good or service” (Besanko et al., 2009). The number of units is the key difference between the two definitions; economies of scale are about reducing the output cost of one unit, economies of scope are gained from the production of more than one unit.

These concepts of economics of scope and scale remain popular due to their power in explaining the growth of multinational corporations (MNCs) in an era of globalisation. Whilst there are prolific theories, i.e. Porter's (1985) competitive advantage work, Dunning's (2000) OLI theory, Barney’s (1991) resource-based view and Ghoshal's (1987) global strategy framework, trying to draw "development trajectories" for MNCs, the two concepts can work with the theories and provide measurable explanations (e.g. marginal cost, turning point from economy to diseconomy of scale) along the trajectories. Nevertheless, most of the research has been focused on manufacturing firms; there is relatively little research into the growth and internationalisation of service firms (Davis, 2004).

Boddewyn et al. (1986) suggest that service firms internationalise for the same reasons as manufacturing firms and so the underlying theoretical assumptions are the same. Capar and Kotabe (2003, p. 348) argued that while some of the theories argue the case for economies of scale for services, they are based on an assumption that service firms "would incur certain fixed costs that are to some extent independent of a company's output”. Segal-Horn (1998, p. 390) suggested that although scale and scope economies could be applied to service firms, the scope for these depended on the sector. She placed professional service firms quite high along the scope-economies scale, but low on the scale-economies axis.

Brock \& Alon (2009, p. 53), in their study of the internationalisation of professional service firms (PSFs), showed that economies of scale and scope, and experiential knowledge could be efficiencies gained by firms expanding overseas. They further explained that "an internationally expanding firm may decrease transactions costs by ((Brock and Alon, 2009, p. 57-58): 
- Spreading fixed costs over larger output, resulting in lower average production costs (Economies of scale);

- Benefiting from shared common resources and increased market power, resulting in lower operating expenses (Economies of scope)

- Gaining experiential knowledge: defined by Blomstermo et al. (2004) as 'knowledge about how to internationalize'.”

Hitt et al. (1997, p. 769) support this view, suggesting that "the coordination required (for multiple transactions among many geographically diverse units) may cost more than the benefits derived from sharing resources and exploiting market opportunities". This coordination becomes much more important as a firm grows and increases the scope of its services and markets.

\section{Scope and scale of international CPS firms}

Putting CPS into context, determining their (dis)economics of scope and scale should be equally complicated, if not more so. For example, ENR divides international CPS markets into six regional market segments (i.e., North America, Europe, Latin America, Asia, the Middle East, and Africa) and ten product segments (i.e., General building, Manufacturing, Power, Water Supply, etc.). According to Lu et al. (2013), CPS could include at least seven multidimensional specialisations such as architecture, engineering, environmental, geotechnical engineering, landscape architecture, urban planning, and surveying. Diversification in services, markets, geographies, or a combination of any of these, is common amongst CPS firms as they aim to leverage greater revenue and profitability from their resources. If using ENR's taxonomies, there are $420(6 \times 10 \times 7)$ different strategy options for a CPS firm to consider in deciding scope, scale, thus the dilemma of scope and scale.

Traditional theories on scope and scale of manufacturing or services firms may be incapable in explaining the dilemma facing CPS firms. For example, the location specificity of CPS means that seeking low-wage locations for facilities does not apply, except in special circumstances, such as locating a computer-aided-design facility in a low-wage economy such as India, as has been the case with a number of the large CPS firms. Equally, labour costs, market access and resources, the drivers for manufacturing company internationalisation cited by Capar and Kotabe (2003) and Boddewyn et al. (1986), are not the deciding factors for CPS firms' strategies. The nature of CPS is that the client dominates, both in the highly customised nature of the services provided, and in that many of the business opportunities are client-led. CPS firms' fixed costs are their built assets and their wage bill, but the latter is dependent on the work available and is often project-based, sometimes with the use of agency staff. 
In summary, international CPS firms are striving to grow and diversify to glean economies of scale and scope whilst trying to avoid hitting the wall of diseconomies of scale and scope. The CPS firms face a dilemma in growing/diversifying to maximise revenue and employee output, while simultaneously being locally responsive to clients to maintain their competitiveness. Traditional theories on manufacturing or general services may not be fully applicable to CPS, which has different characteristics. This situation is further complicated by the international dimension in their growth/diversification. An in-depth understanding of the dilemma in international CPS firms is highly desired.

\section{Methodology}

The sample was selected from the largest CPS firms taken from the ENR's Top 150 Global Design Firms in 2013. The Top 150 Global Design Firms list, published annually in July, ranks the 150 largest world designs firms, both publicly and privately held, based on total design-specific revenue in the past year regardless of where the projects were located (ENR, 2013). According to ENR, design here refers to architecture, engineering, environmental, geotechnical engineering, landscape architecture, urban planning, surveying, and their combinations, which can be treated equally as CPS discussed in this paper.

Information was accessible for the publicly-quoted firms in the top 25, but, for private firms, getting this type of information was not always possible. Some companies in the Top 150 firms are not strictly independent design and engineering consultants, being more Engineer Procure and Construct contractors. Therefore, the sample was narrowed to 17 firms out of the top 25. The study aimed to understand the growth/diversification of the top CPS companies through the 17 firms. Although they do happen, it is difficult for CPS firms to measure any economies of scope and scale they may have achieved through growth/diversification, because their output is "intangible services encoded with complex knowledge" (Greenwood et al., 2005). They have a high fixed-to-variable cost ratio. Therefore, this research analyses the growth timelines of the top global CPS companies to better understand how they have grown. Two measures are used. One is mergers and acquisition (M\&A) activity as a metric for organic or inorganic growth. Low M\&A activity suggests a focus on organic growth; high activity is a sign of inorganic growth. The second is diversification as this has associated advantages of economies of scope, scale and learning (Ghoshal, 1987, Kim et al., 1993). The level and type of diversification are indicative of a firm seeking economies of scope and scale.

The timelines produced - Figure 1 gives an example - showed the number of mergers, acquisitions and divestitures; whether they were with overseas companies (dotted line) or 
domestic companies (solid line), and; whether the acquired firm was within the same service area as the acquiring firm (white circle) or otherwise (different shape). A brief description of each of the selected firms (from their company website) is given on the timeline and background information was compiled giving the name of the acquired firm with its associated number so that it could be identified on the timeline. The data sources for the timelines include company annual reports and published analyst/financial reports.

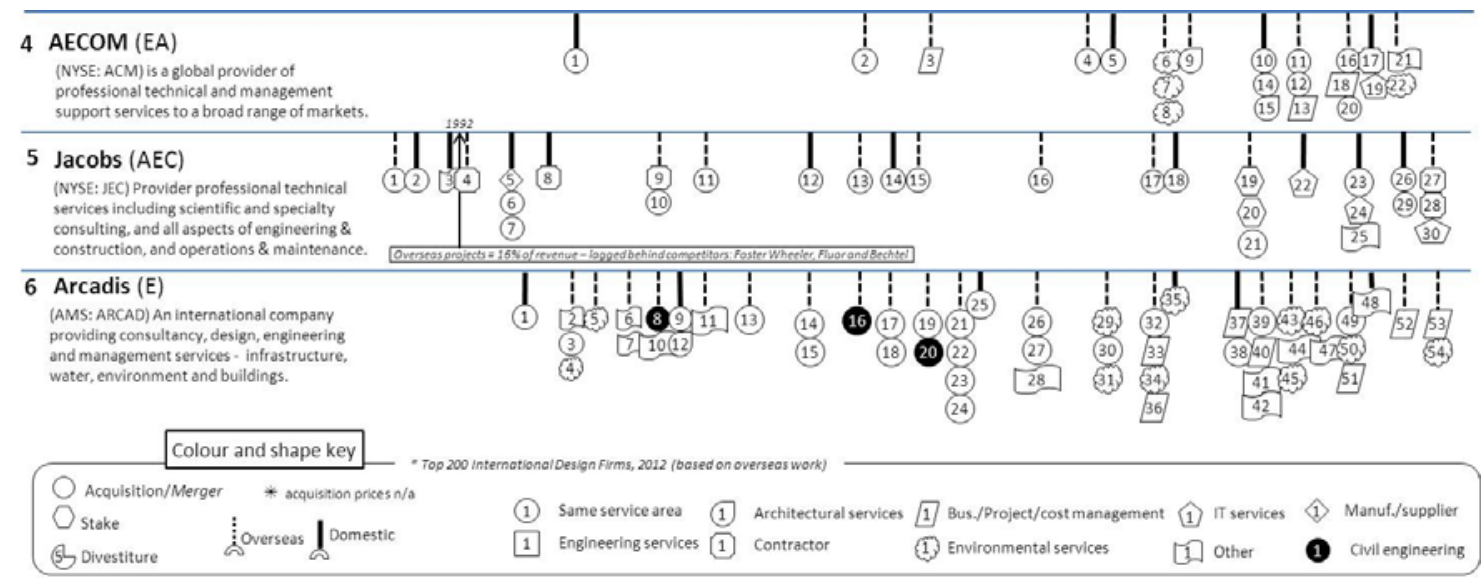

Figure 1 An excerpt from "the timelines" developed to understand growth/diversification strategies of international CPS firms

Furthermore, interviews were conducted to gain insights into the growth/diversification strategies of international CPS firms, as the annual reports rarely tell the motives behind the strategies. Table 1 summarises the basic information of the interviewees, which were either CEOs or part of top management of the firm, they were able to give a highly expert and knowledgeable view of the firm's strategy. According to the interview protocol, the information that can help identify them is not to be released here.

Table 1 Basic information of the interviewees

\begin{tabular}{|l|l|l|}
\hline Code & Position Held & Companies Specialization \\
\hline A & Chief Executive - Europe & $\begin{array}{l}\text { A global provider of professional technical and management } \\
\text { support services }\end{array}$ \\
\hline B & $\begin{array}{l}\text { Chief Operating Officer }- \\
\text { UK \& Middle East }\end{array}$ & $\begin{array}{l}\text { Firm of designers, planners, engineers, consultants and technical } \\
\text { specialists }\end{array}$ \\
\hline C & Chief Executive & $\begin{array}{l}\text { Planning and design; Transportation and mobility; Water and } \\
\text { energy }\end{array}$ \\
\hline D & Chief Executive & Planning, design and management services \\
\hline
\end{tabular}




\begin{tabular}{|l|l|l|}
\hline E & Chairman & Management, engineering and development consultancy \\
\hline F & $\begin{array}{l}\text { Managing Director and } \\
\text { Group CEO }\end{array}$ & Engineering and design consultancy \\
\hline G & Chairman & Multi-disciplinary design and engineering consultancy \\
\hline H & President and CEO & $\begin{array}{l}\text { Architecture, structural engineering, building service systems, } \\
\text { infrastructure, water and environment, project management, } \\
\text { energy, geographical IT }\end{array}$ \\
\hline I & Chief Operating Officer & Engineering, construction and technical services \\
\hline J & Chief Executive & $\begin{array}{l}\text { Property; transport and infrastructure; environment and energy, } \\
\text { and; industrial }\end{array}$ \\
\hline
\end{tabular}

The interview questions are listed in Table 2. Based on the authors' experience and the preceding literature review, these questions were designed in a way that allowed for some general "chat" with the interviewees at the beginning and for more specific viewpoints thereafter. The graphic tools in Question 4 were designed to facilitate the interviewees' to organise their thoughts. The interviews were either face-to-face or by telephone between January and April 2011. The two parts of data from the timeline analyses, and interviews, will be indicated differently, with interview data shown in italics, but were placed together to ensure an uninterrupted reading journey in this paper.

Table 2 A list of the interview questions

\begin{tabular}{|l|l|}
\hline 1 & Is your firm's export business organised on a regional or country basis? \\
\hline 2 & Is your accounting system based on business or geographic units, or both or neither? \\
\hline 3 & $\begin{array}{l}\text { Is your firm global, multinational, international or transnational? } \\
\text { The interviewees were given the model for each of these based on Bartlett and } \\
\text { Ghoshal's (1998) typology. }\end{array}$ \\
\hline 4 & $\begin{array}{l}\text { What is the firm's growth strategy in terms of markets and services? } \\
\text { The interviewees were asked to place themselves on a strategy matrix - an adaptation } \\
\text { of Ansoff's (1957) matrix for manufacturing( see below left), and a growth matrix (see } \\
\text { below right). }\end{array}$ \\
\hline
\end{tabular}




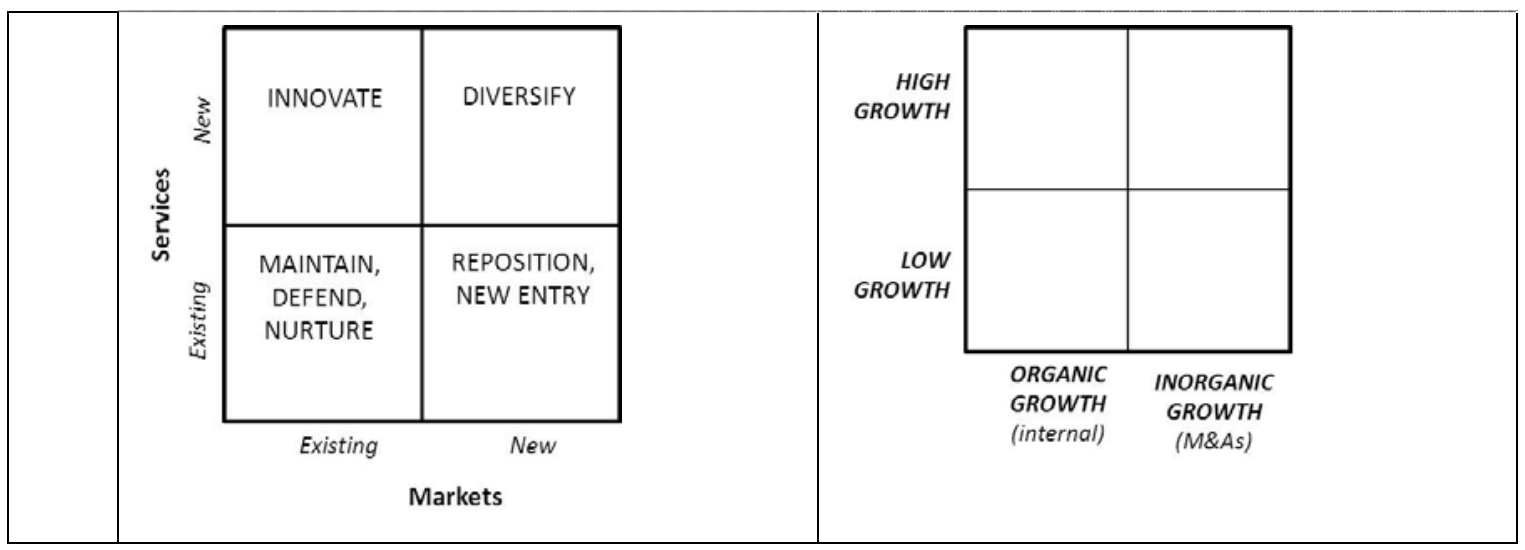

Analyses, discussions, and findings

The timelines and interviews

The M\&A timelines in figures 2-4 show graphically the CPS firms' desire to grow. Some of the firms do not have a strong acquisition culture, for example, Fluor, Arup and Ramboll, these firms are growing organically and sustaining a position amongst the top ranked CPS firms. 


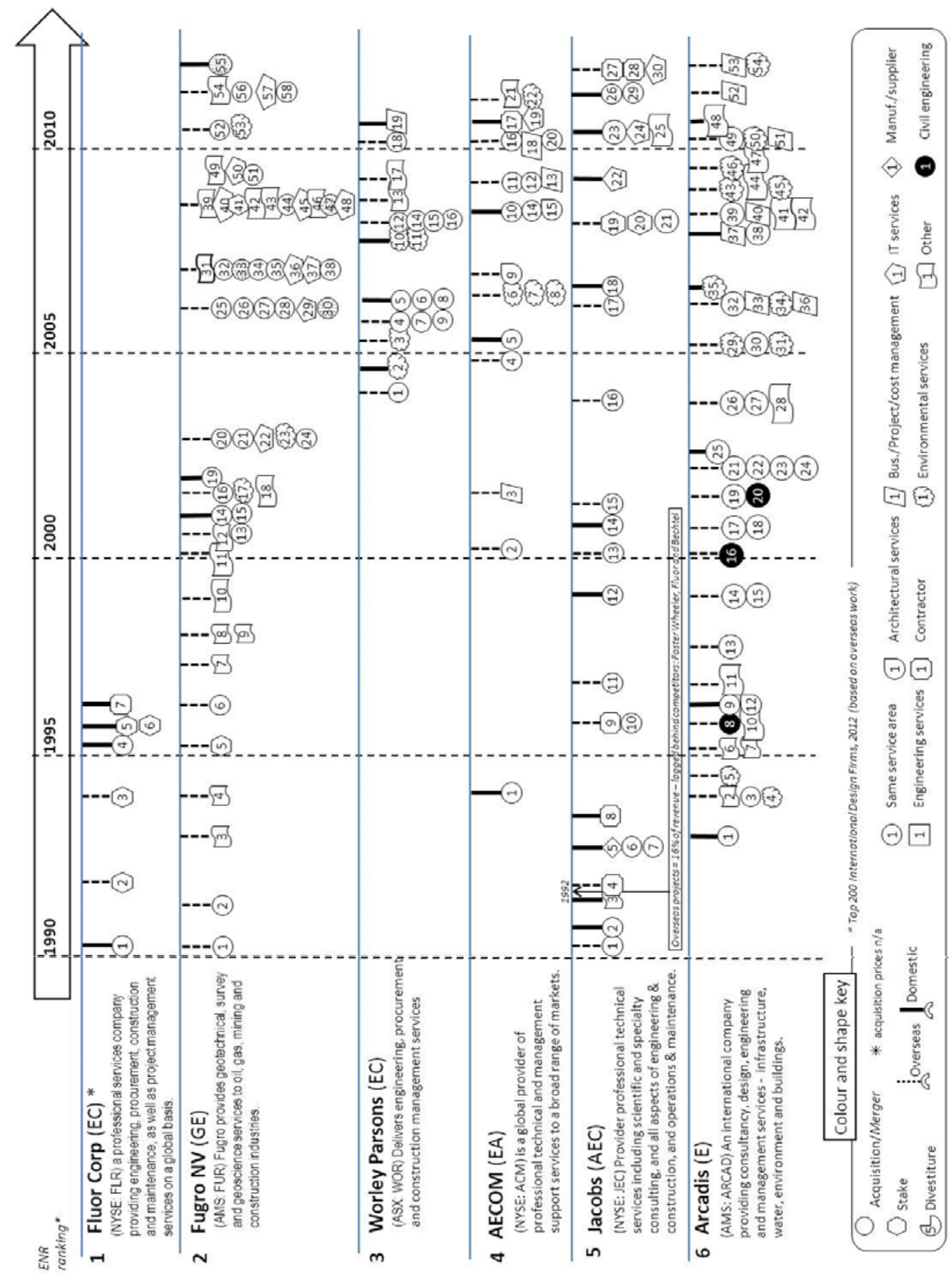

Figure 2 "the timelines" 


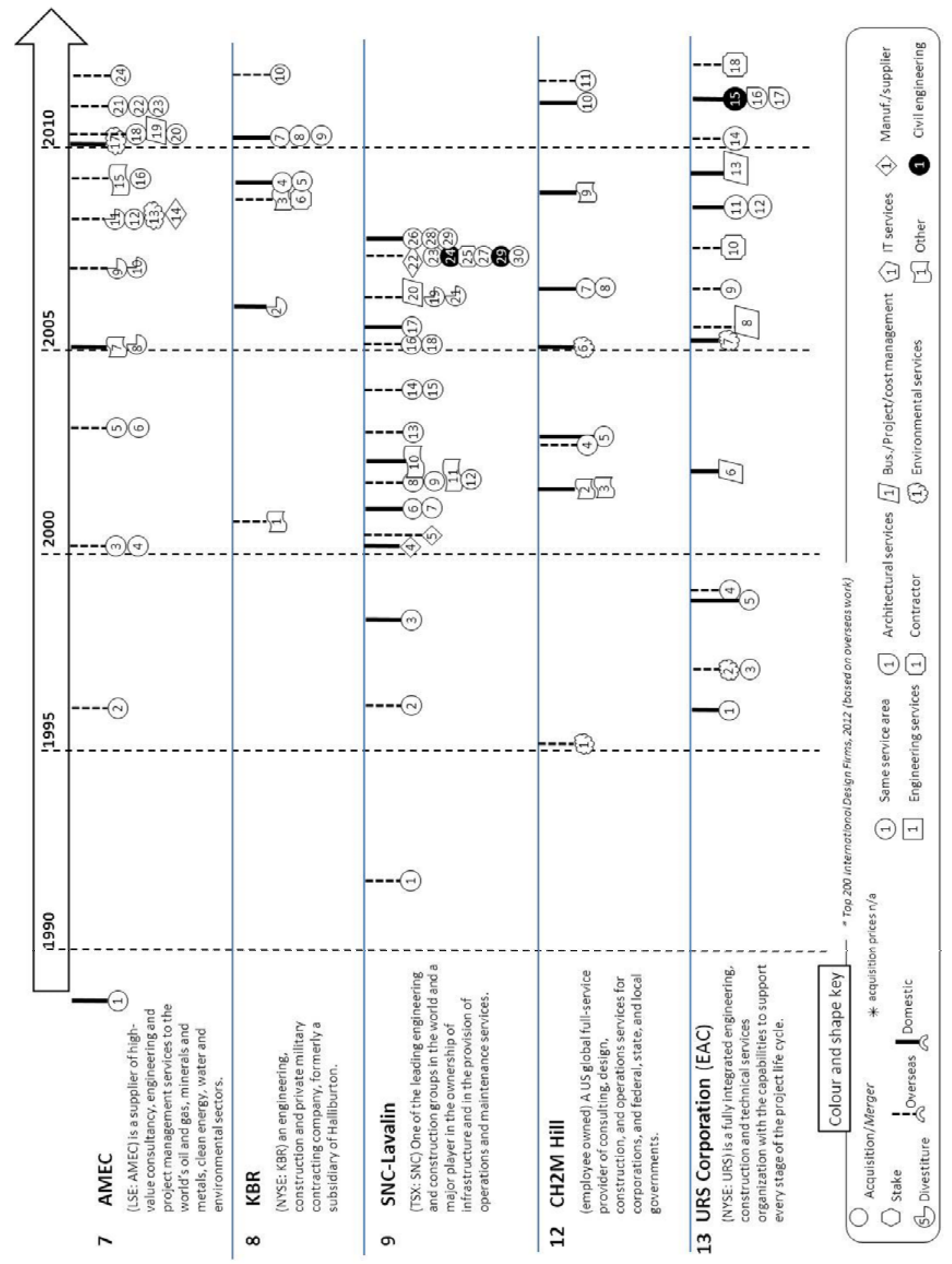

Figure 3 “the timelines” (continue 1) 


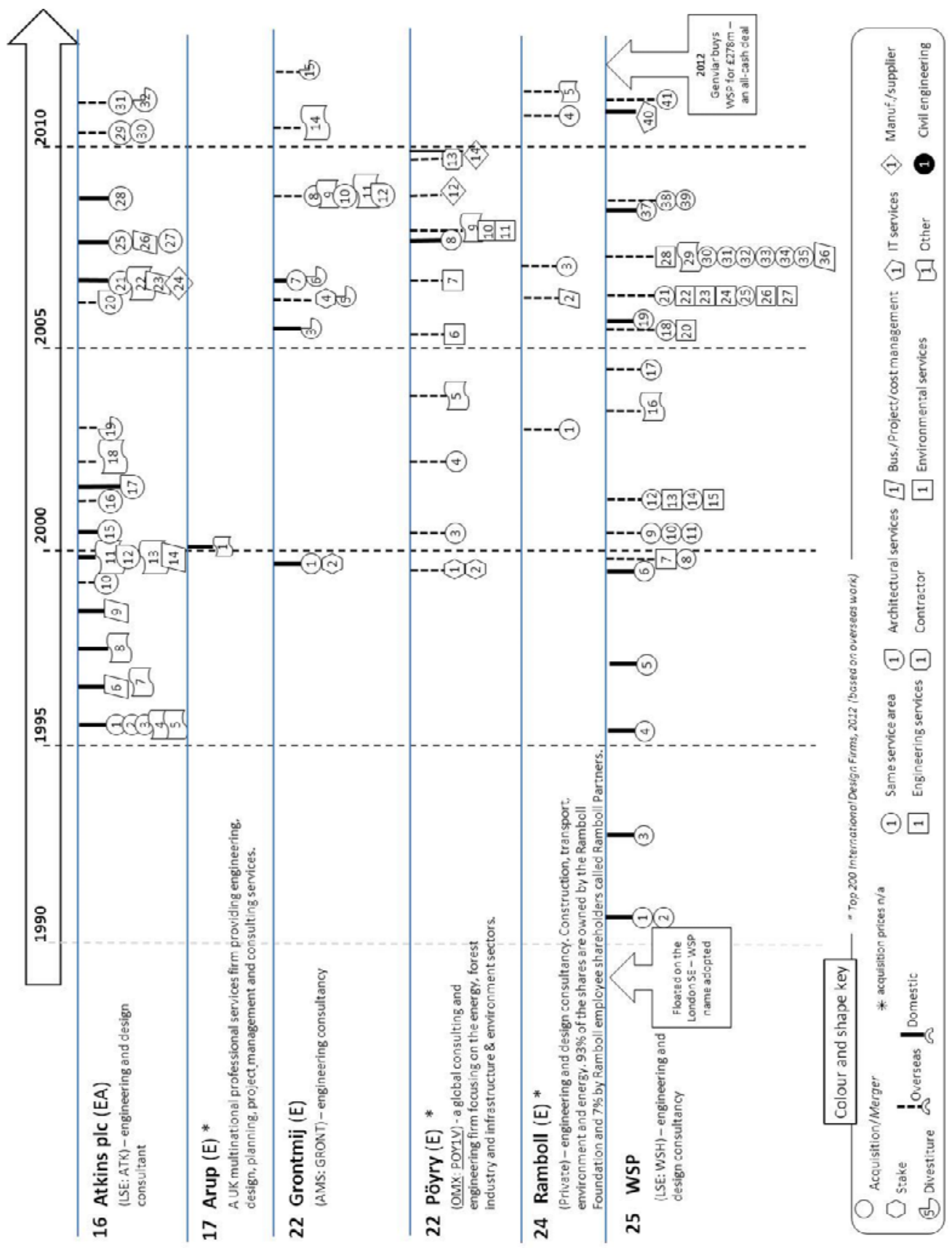

Figure 4 “the timelines” (continue 2)

The timelines also show the extent of the firms' diversification into different markets and services. In some cases the acquisition has been an example of vertical integration, taking over upstream suppliers/manufacturers. For example, Fugro NV acquired companies producing remote-controlled vehicles, jack-up rigs and a cable manufacturer. Whilst vertical integration can provide economies of scale, horizontal integration (same industry/same stage 
of production) can provide both economies of scope and scale. Similarly, Arcadis as shown in Figure 1 has also been actively in diversifying into different specifications such as design, engineering, and management services, in both domestic and overseas markets, which successfully elevated itself to being one of the top CPS firms.

Whilst the timeline is an effective tool to give a view of the patterns of growth and diversification, the motives behind these are not clear. Moreover, whether these companies hit the wall of diseconomies of scope and scale is not clear from the timelines. The interviews in this study were undertaken to fill that gap.

The companies recognised that while increasing internationalisation provides the possibility of greater production (greater scale), the highly customised nature of their services means that only certain parts of the business can reap economies of scale. As one of the companies interviewed explained “.... the consultancy business is local ... the basic platform for being a consultant will be local with a need to understand the client and the local issues." The services that could enable economies of scale to be achieved are those provided by the head office on a company/group wide scale such as human resource management, IT, and knowledge management processes. One of the interviewed companies explained that a "solid cross-border capability" is important for growing the business; they have a "common human resources framework, which is driven by, and feeds into, the business-line structure and our cross-border ambitions".

The interviewed firms described the growth strategies that extend their scope. The majority adopts a policy of inorganic growth; the rest used a combination of inorganic and organic growth. Organic growth is growth generated from the company's existing resources; inorganic growth involves strategies such as mergers, acquisitions, joint ventures and so on. Whatever the strategy, the aim was to maximise the capabilities and competencies of the firm/group's employees to achieve the best combination to meet the client's needs, and to ensure the firm remained profitable. How this is done is very dependent on global and local economic climates; as one interviewee stated: "in current markets, we're all desperately diversifying, maintaining, defending and nurturing as well as everything else we're doing”. Whilst diversification was a common strategy amongst the companies, their focus on core competencies was highlighted in the interviews. One CEO said "By focusing on core competences, we are positioned to pursue organic growth in the most profitable and fastest growing markets".

A CPS firm's core competencies are the sum of its knowledge assets dependent on the intrinsic and shared knowledge of its employees (Kandampully, 2002 ). Knowledge is key to 
CPS firms; according to one of the firms interviewed "Consultancy firms are complex, the delivery is local but the knowledge has to be shared." Scarso and Bolisani (2010) suggest that the sharing of knowledge assets is a core competence in itself. One of the interviewed firms described how they achieve economies of scope by widening the range of services in a country in which they are already established. They explained "We try and infill, so if we're say selling transport in Poland, we will try and extend that to water, energy and other sectors where we have strong capability."

\section{Factors determining the patterns of scope and scale}

Based on the above analyses of the timelines and interviews, it is clear that CPS firms are facing a dilemma. Successful firms seek economies of scope and scale, but need to maintain a strong local presence and focus on the needs of their clients. A triangulation of the interviews and the literature shows that eight factors influence how the dilemma is dealt with: growth

strategy, profitability, competitiveness, reputation, serving the client needs, internationalisation, localisation, and ownership constraints.

\section{Growth strategy}

Economies of scope and scale are the result of growth (Schwenker and Bötzel, 2007). The interviewees considered growth to be paramount and were unanimous in saying that a firm that does not grow would be considered stagnant and unattractive to the market and, most importantly, to potential employees. Growth is seen as a measure of success. For a CPS firm, it is not only measured in annual revenue but the number of employees and, in particular, their level of experience and expertise. The interviews implied that strategies of growth, such as organic and inorganic, and the level of growth are important differentiators of CPS firms. For example, as aforementioned, Fluor, Arup, and Ramboll tend to grow organically, while others (e.g. Jacob) tend to adopt an aggressive M\&A strategy.

\section{Profitability}

Profitability is an important measure in any firm, it was not possible to undertake a rigorous statistical analysis, but the gross profitability before tax of the CPS firms was in the range 4.6\%-9.0\%, dependent on the market situation. The ACE (2012) Annual Benchmarking Report shows this to be consistent with the findings. Hence, increases in scale should be reflected in higher gross profits. The publicly quoted CPS firms will have a stronger emphasis on profitability as ultimately it impacts their share price and the market capitalisation of the business. An employee-owned Trust will be aware of the risks being taken, similar to a Partnership, and the impact on the share value.

\section{Competitiveness}


Seeking economies of scope and scale is motivated by the need to remain competitive both in price and service. A CPS firm offers a highly customised and localised service and so relies on its collective knowledge as a competitive advantage. Because of the nature of selecting a CPS firm often being based on service, quality and reputation, price is less dominant than in the case of construction companies bidding for work. However, price competitiveness is more prevalent in a highly competitive market. Competitiveness is closely related to the reputation of the CPS firm and its efficiency in managing its overheads and production costs.

\section{Reputation}

Reputation is crucial to CPS firms that are knowledge-intensive and totally reliant on the expertise, knowledge and reputation of its employees. The role of reputation is two-fold: firstly a firm's reputation needs to be good enough to attract clients/business, and secondly it needs to be able to attract the best people, a CPS firm's greatest asset. Economies can be achieved through a good reputation as clients themselves will actively seek higher status firms thus reducing marketing costs (Greenwood et al., 2005).

\section{Serving the client's needs}

The nature of CPS firms is that the client dominates; both in the highly customised nature of the services provided, and in that many of the business opportunities are client-led. CPS firms are very client focused; the sample showed that some of the larger firms have $70 \%$ of their revenue from $30 \%$ of their clients. Hence, they are focused on repeat business and serving the client wherever they may venture. CPS firms have to find new ways of standardising the quality of service provided by their dispersed offices to achieve economies of scope, while simultaneously maintaining a customer focus. The internationalising strategy of a client is often the motive for a CPS firm to internationalise (Winch, 2008).

\section{Internationalisation}

The CPS sector is one of the largest internationally-traded services sector (Winch, 2008). Globalisation has prompted increasing numbers of CPS firms to internationalise and export their services; it has transformed the structures and strategies of large CPS firms. The timelines showed the extent of internationalisation through mergers and acquisitions and the interviews reiterated the importance of internationalisation in achieving economies of scope and scale.

\section{Localisation}

Internationalising a CPS firm involves embracing localisation. CPS firms are governed by strict rules and regulations about their professional practice (Nguyen-Hong, 2000), which means that being local and acting local with all the compliance requirements is becoming a 
pre-requisite for success. The CPS firms are more inclined to establish a local sustainable presence rather than seeking work on a project by project basis; the interviews confirmed that continuity of business was a pre-requisite for growth. Similarly, many of the CPS firms followed their clients overseas to service their needs. Localisation adds to the CPS firms' dilemma of how big to grow. Becoming a multinational with high global integration in order to achieve economies of scope and scale may compromise the firms' ability to be locally responsive (Prahalad and Doz, 1987).

\section{Ownership constraints}

The ownership structure of the CPS firm reflects the risk and the strategy. As a partnership, any acquisition or new venture will need to be paid from reserves, profits, or loans. The owners will be party to the decision to expand the scale and scope. In a public company the acquisition is more transparent and can be paid by issuing new shares or by a shares and cash arrangement. The Board and leadership of the company will be strongly influenced by the public perception and the likely rewards for the shareholders. Many CPS firms have evolved from a partnership, to a limited liability partnership, to either a publicly-quoted firm, or a firm controlled by a Trust. Ownership through a Trust is based on employee ownership rather than control by the Partners or (public) shareholders. These firms normally do not have a strong acquisition culture, for example, Fluor, Arup and Ramboll grow organically and sustain a position amongst the top-ranked CPS firms. Arup and Ramboll are both privately owned; Arup is owned by a Trust and the Ramboll shares are owned by the Ramboll Foundation. From the interviews, it was clear that ownership had an impact on firms' growth strategies.

\section{Conclusions}

Recent years have witnessed that many top international CPS firms have grown and diversified into different professional disciplines and geographic markets to glean economies of scale and scope. The pressures of needing to be local, but having a global presence, have prompted many large/mega CPS firms to increase both the scope of their competencies and the scale of their operations. However, growth can lead to diseconomies of scale, when the added cost of extra production and the increased complexity of diversification no longer create benefits. The CPS firms face a dilemma in growing/diversifying to maximise revenue and employee output, and simultaneously being locally responsive to clients.

It is found that CPS firms can achieve economies of scale/scope through organic or inorganic growth, dependent on a CPS firm's growth strategy. This strategy is further influenced by a number of factors, eight were identified in the research: growth strategy, profitability, competitiveness, reputation, serving the client needs, internationalisation, localisation, and ownership constraints. Each of these factors is not mutually exclusive and they are all 
interdependent.

The research provides new insights into the internationalisation of CPS firms, particularly their growth and diversification strategies, by critiquing the inapplicability of traditional theories and analytical tools developed from the manufacturing or general services industries. The timeline developed in this study is an effective tool to investigate CPS firms' growth and diversification strategies over time. The eight factors determining the choice of growth and diversification strategies could be useful building blocks for an analytic framework to understand the dilemma of scope and scale for international CPS firms. Measuring the success of increases in scope and scale and the metrics associated with the factors are being further investigated.

\section{References}

ACE 2012. ACE Benchmarking Report: Industry Overview 2012. London: Association for Consultancy and Engineering.

ANSOFF, I. 1957. Strategies for Diversification. Harvard Business Review, Vol. 35, 113-124.

BAILEY, E. E. \& FRIEDLAENDER, A. F. 1982. Market Structure and Multiproduct Industries. Journal of Economic Literature, 20, 1024-1048.

BARNEY, J. B. 1991. Firm Resources and Sustained Competitive Advantage. Journal of Management, 17, 99-120.

BARTLETT, C. \& GHOSHAL, S. 1998. Managing across borders. The transnational solution, Boston, Harvard Business School Press.

BESANKO, D., DRANOVE, D., SHANLEY, M. \& SCHAEFER, S. 2009. Economics of Strategy, John Wiley.

BLOMSTERMO, A., ERIKSSON, K., LINDSTRAND, A. \& SHARMA, D. D. 2004. The Perceived Usefulness of Network Experiential Knowledge in the Internationalizing Firm. Journal of International Management Decision, 10, 355-374.

BODDEWYN, J. J., HALBRICH, M. B. \& PERRY, A. C. 1986. Service Multinationals: Conceptualization, Measurement and Theory. Journal of International Business Studies, 17, 41-57.

BROCK, D. M. \& ALON, I. 2009. Internationalization of professional service firms International Business: Research Teaching and Practice, 3, 52-70.

CAPAR, N. \& KOTABE, M. 2003. The Relationship between International Diversification and Performance in Service Firms. Journal of International Business Studies, 34, 345-355.

DAVIS, T. R. V. 2004. Different service firms, different international strategies. Business Horizons, 47, 51-59.

DUBOIS, A. \& GADDE, L. E. 2002. The construction industry as a loosely coupled system: 
implications for productivity and innovation. Construction Management and Economics, 20, 621-631.

DUNNING, J. H. 2000. The eclectic paradigm as an envelope for economic and business theories of MNE activity. International Business Review, 9, 163-190.

ENGINEERING NEWS RECORD 2013. Top 250 Global Designers. ENR. USA: McGraw Hill Financial.

GANN, D. M. 1996. Construction as a manufacturing process? Similarities and differences between industrialized housing and car production in Japan. Construction Management and Economics, 14, 437-450.

GHOSHAL, S. 1987. Global strategy: an organizing framework. Strategic Management Journal, 8, 425-440.

GREENWOOD, R., LI, S. X., PRAKASH, R. \& DEEPHOUSE, D. L. 2005. Reputation, Diversification, and Organizational Explanations of Performance in Professional Service Firms. Organization Science, 16, 661-673.

HATZICHRONOGLOU, T. 1996. Globalisation and Competitiveness: Relevant indicators. OECD Science, Technology and Industry Working Papers1996/05. Paris: OECD Publishing.

HITT, M. A., HOSKISSON, R. E. \& HICHEON, K. 1997. International Diversification: Effects on Innovation and Firm Performance in Product-Diversified Firms. The Academy of Management Journal, 40, 767-798.

JEWELL, C. A. 2011. A typology of construction professional services firms- a consulting engineering perspective. Unpublished $\mathrm{PhD}$ thesis, University of Reading, $\mathrm{UK}$.

JEWELL, C. A., FLANAGAN, R. \& ANAC, C. (2010). Understanding UK construction professional services exports: definitions and characteristics. Construction Management and Economics, 28 231-239.

KANDAMPULLY, J. 2002 Innovation as the core competency of a service organisation: the role of technology, knowledge and networks. European Journal of Innovation Management, Volume 5, 18-26.

KIM, W. C., HWANG, P. \& BURGERS, W. P. 1993. Multinationals' Diversification and the Risk-Return Trade-Off. Strategic Management Journal, 14, 275-286.

LøWENDAHL, B.R. 2007. Professional Service Firms. Copenhagen Business School Press, Copenhagen.

LU, W.S., YE, K.H., FLANAGAN, R. \& JEWELL, C.A. 2013. Developing Construction Professional Services in the International Market: A SWOT Analysis of China. Journal of Management in Engineering, ASCE. 29 (3), 302-313.

MALCIC, L. 2011. Squaring the circle: delivering international services locally. In: SMYTH, H. (ed.) Managing the professional practice in the built environment. Chichester: Wiley-Blackwell. 
MCCANN, J. E. 1996. The growth of acquisitions in services. Long Range Planning, 29, 835-841.

NAYYAR, P. R. 1993. Performance Effects of Information Asymmetry and Economies of Scope in Diversified Service Firms. The Academy of Management Journal, 36, 28-57.

NGUYEN-HONG, D. 2000. Restrictions on Trade in Professional Services (August 16, ). . Productivity Commission Discussion Paper No. 1638.

OECD. 2011. OECD Glossary of Statistical Terms [Online]. [Accessed 18/07/11].

ONS 2007. UK Standard industrial Classification of Economic Activities 2007 (SIC 2007).

PANZAR, J. C. and WILLIG, R.D. (1977). Economies of Scale in Multi-Output Production. Quarterly Journal of Economics, 91(3), pp. 481-493.

PANZAR, J. C. and WILLIG, R.D. (1981). Economies of Scope. American Economic Review, 71(2), 71(2), pp. 268-272.

PORTER, M. E. 1985. Competitive Advantage, New York, Free Press.

PRAHALAD, C. K. \& DOZ, Y. L. 1987. The multinational mission: Balancing local demands and global vision, New York, The Free Press.

REINA, P. \& TULACZ, G. J. 2011. The Top 200 International Design Firms. ENR: Engineering News-Record, 7/25/2011, Vol. 267, Issue 3.

SCARSO, E. \& BOLISANI, E. 2010. Knowledge-Based Strategies for Knowledge Intensive Business Services: a Multiple Case-study of Computer Service Companies. Electronic Journal of Knowledge Management, Volume 8, 151 - 160.

SCHWENKER, B. \& BÖTZEL, S. 2007. Making growth work: How Companies Can Expand and Become More Efficient, Berlin, Heidelberg, New York, Springer.

SEGAL-HORN, S. 1998. The internationalization of service firms. In: SEGAL-HORN, S. (ed.) The strategy reader. Milton Keynes, Oxford and Malden, M.A.: Blackwell Publishers in association with the Open University.

SEGAL-HORN, S. 2003. Strategy in service organizations. In: FAULKNER, D. O. \& CAMPBELL, A. (eds.) The Oxford Handbook of Strategy. Oxford: Oxford University Press.

WINCH, G. M. 2008. Internationalisation strategies in business-to-business services: the case of architectural practice. Service Industries Journal, 28, 1-13. 